\title{
BMKGsoft Quality Measurement Using COBIT Framework 5 Case Study: Teluk Bayur Maritime Meteorological Station \\ (Pengukuran Kualitas BMKGsoft Menggunakan Framework COBIT 5 Studi Kasus : Stasiun Meteorologi Maritim Teluk Bayur)
}

\author{
Fajrin Rizaldi ${ }^{1}$, Aggy Pramana Gusman ${ }^{2}$, Ulya Mega Wahyuni ${ }^{3}$ \\ ${ }^{1,2}$ Universitas Putra Indonesia "YPTK" Padang, Indonesia \\ ${ }^{3}$ Universitas Andalas, Indonesia \\ Email: rizaldifajrin@gmail.com,
}

\begin{abstract}
BMKGsoft is a website owned by BMKG that is used to enter certain data obtained. Governance is a structure of relationships and processes to direct and control the organization to achieve its objectives. In this study using the COBIT framework (Control objectives for information and related technologies) version 5, the selected domain in the study was the EDM, APO, DSS, and MEA domains. In the research done overall the average obtained is 2.96 with a maturity scale is on a scale of 3.
\end{abstract}

Keywords: Governance, Cobit 5, Maturity Level

\begin{abstract}
Abstrak
BMKGsoft merupakan suatu website yang dimiliki oleh BMKG yang digunakan untuk menginputkan data-data tertentu yang diperoleh. Tata kelola merupakan struktur hubungan dan proses untuk mengarahkan dan mengendalikan organisasi untuk mencapai tujuan. Dalam penelitian ini menggunakan kerangka kerja COBIT (Control Objective For Information and Related Technology) versi 5, Domain yang dipilih dalam penelitian ini adalah domain EDM, APO, DSS, dan MEA. Pada penelitian yang dilakukan rata-rata keseluruhan yang diperoleh adalah 2,96 dengan skala kematangan berada di skala 3 .
\end{abstract}

Kata kunci: Tata Kelola, Cobit 5, Tingkat Kematangan

\section{Pendahuluan}

\subsection{Latar Belakang}

BMKGsoft ditujukan untuk membantu stasiun meteorologi maritim teluk bayur menginputkan data yang akan disimpan di database perusahaan sehingga saat data tersebut dibutuhkan, maka pihak yang membutuhkan hanya perlu mencari pada database perusahaan tersebut. Sistem ini digunakan untuk mengolah data cuaca yang diterima dari alat yang terpasang dan dioperasikan oleh pihak Badan Meteorologi Klimatologi dan Geofisika itu sendiri. Stasiun Meteorologi Maritim Teluk Bayur adalah salah satu kantor cabang Badan Meteorologi Klimatologi dan Geofisika yang menggunakan sistem tersebut dan penginputan data dilakukan setiap hari. Sistem BMKGsoft ini sendiri mulai digunakan di Stasiun Meteorologi Maritim Teluk Bayur sejak tahun 2013. Dan sistem ini sebelumnya menggunakan database sendiri yang ada di komputer atau pc masing-masing. Maka pengembangan di lakukan oleh pihak BMKG agar database yang terhubung hanya satu yaitu di kantor pusat BMKG yang ada di jakarta. Sistem ini sendiri sebelumnya sudah mengalami maintenance sebanyak 2 kali. Tetapi bukan maintenance yang menjurus pada sistem langsung, tetapi dengan hanya mengganti komputer atau pc yang ada karena database sistem tersebut ada di komputer atau pc masing-masing. Tata kelola dilakukan dengan tujuan meningkatkan keuntungan dan mengurangi kelemahan. Dengan melakukan tata kelola maka perusahaan dapat berjalan lebih baik dan tujuan perusahaan dapat dicapai. Dalam penelitian yang dilakukan digunakan framework COBIT 5 untuk melakukan penilaian kualitas tata kelola teknologi informasi. Dengan melakukan penelitian maka pihak yang berkepentingan akan mengetahui sejauh mana kinerja sistem, serta mengetahui berapa nilai tertentu dari setiap pengelolaan yang dilakukan di perusahaan. COBIT 5 adalah salah satu kerangka bisnis untuk tata kelola dan manajemen perusahaan IT. Versi evolusiner ini menggabungkan pemikiran terbaru dalam tata kelola perusahaan dan teknik manajemen, serta menyediakan prinsip-prinsip, praktek, alat-alat analisis dan model yang diterima secara global untuk membantu meningkatkan kepercayaan, dan nilai dari sistem informasi[1]. Karena sebelumnya penelitian menggunakan framework COBIT sudah dilakukan, maka penulis dapat menggunakan penelitian terdahulu tersebut sebagai salah satu rujukan dalam melakukan penelitian. Dan untuk mengetahui sejauh mana tata kelola teknologi informasi dilakukan dapat dilihat berdasarkan indeks kematangan. Adapun skala tata kelola sistem informasi berjalan di perusahaan dapat dilihat pada tabel dibawah ini[2] : 
Tabel 1.1 Indeks Kematangan COBIT 5

\begin{tabular}{cl}
\hline Indeks Kematangan & \multicolumn{1}{c}{ Tingkat Kematangan } \\
\hline $0-0,49$ & $0-$ Non Existent \\
\hline $0,50-1,49$ & $1-$ Initial / Ad Hoc \\
\hline $1,50-2,49$ & $2-$ Repeatable But Intuitive \\
\hline $2,50-3,49$ & $3-$ Defined Process \\
\hline $3,50-4,49$ & $4-$ Managed And Measurable \\
\hline $4,50-5,00$ & $5-$ Optimized \\
\hline
\end{tabular}

Keterangan masing-masing level seperti penjelasan dibawah ini :

a. Non-Existent

Kekurangan yang menyeluruh terhadap proses apapun yang dapat dikenali. Perusahaan bahkan tidak mengetahui bahwa terdapat permasalahan yang harus diatasi.

b. Initial / Ad Hoc

Terdapat bukti bahwa perusahaan mengetahui adanya permasalahan yang harus diatasi. Bagaimanapun juga tidak terdapat proses standar, namun menggunakan pendekatan ad hoc yang cenderung diperlakukan secara individu atau per kasus. Secara umum pendekatan kepada pengelolaan proses tidak terorganisasi.

c. Repeatable But Intuitive

Proses dikembangkan ke dalam tahapan yang prosedur serupa diikuti oleh pihak-pihak yang berbeda untuk pekerjaan yang sama. Tidak terdapat pelatihan formal atau pengkomunikasian prosedur standar dan tanggung jawab diserahkan kepada individu masing-masing. Terdapat tingkat kepercayaan yang tinggi terhadap pengetahuan individu sehingga kemungkinan terjadi error sangat besar.

d. Defined Process

Prosedur distandarisasi dan didokumentasikan kemudian dikomunikasikan melalui pelatihan. Kemudian diamanatkan bahwa proses-proses tersebut harus diikuti. Namun penyimpangan tidak mungkin dapat terdeteksi. Prosedur sendiri tidak lengkap namun sudah memformalkan praktek yang berjalan.

e. Managed And Measurable

Manajemen mengawasi dan mengukur kepatutan terhadap prosedur dan mengambil tindakan jika proses tidak dapat dikerjakan secara efektif. Proses berada dibawah peningkatan yang konstan dan penyediaan praktek yang baik. Otomatisasi dan perangkat digunakan dalam batasan tertentu.

f. Optimized

Proses telah dipilih ke dalam tingkat praktek yang baik, berdasarkan hasil dari perbaikan berkelanjutan dan permodelan kedewasaan dengan perusahaan lain. Teknologi informasi digunakan sebagi cara terintegrasi untuk mengotomatisasi alur kerja, penyediaan alat untuk peningkatan kualitas dan efektifitas serta membuat perusahaan cepat beradaptasi [ $\underline{3}]$.

\section{Metodologi Penelitian}

Dalam penelitian ini, penulis menggunakan COBIT versi 5 untuk melakukan penilaian tata kelola teknologi informasi yang ada di perusahaan. Tata kelola itu sendiri dilakukan penilaian guna melihat apakah tata kelola sudah berjalan dengan baik atau belum. Dengan tata kelola dilakukan dengan baik maka dapat mengurangi beberapa aspek dan meningkatkan keuntungan bagi perusahaan itu sendiri. 


\section{Analisa dan Hasil}

\subsection{Identifikasi Proses Teknologi Informasi}

Pada tahap ini menetapkan proses teknologi informasi yang sesuai dengan standar COBIT 5 terkait dengan permasalahan yang terdapat pada Stasiun Meteorologi Maritim Teluk Bayur. Adapun susunan menurut domain yang akan digunakan adalah ditunjukkan pada tabel 3.1 sebagai berikut :

Tabel 3.1 Tabel Proses Teknologi Informasi

\begin{tabular}{ll}
\hline \multicolumn{1}{c}{ IT Domain } & \multicolumn{1}{c}{ IT Proses } \\
\hline Evaluate, Direct, and Monitoring & EMD 03, EDM 04 \\
\hline Align, Plan, and Organise & APO 01, APO 02, APO 06, APO 07 \\
\hline Deliver, Service, and Support & DSS 01, DSS 03 \\
\hline Monitor, Evaluate, and Asses & MEA 01, MEA 03 \\
\hline
\end{tabular}

\subsection{Identifikasi Control Objective}

Setiap proses IT pada COBIT 5 memiliki aktivitas pada tiap proses, yang merupakan alat control dari proses IT tersebut. Aktivitas pada proses IT yang digunakan pada penelitian ini dapat dilihat pada tabel 3.2 sebagai berikut

Tabel 3.2 Aktivitas Proses Teknologi Informasi

\begin{tabular}{|c|c|c|}
\hline Proses IT & Aktivitas Proses & Deskripsi Aktivitas \\
\hline \multirow{3}{*}{ EDM 03} & EDM 03.01 & Evaluate risk management \\
\hline & EMD 03. 02 & Direct risk management \\
\hline & EDM 03. 03 & Monitor risk management \\
\hline \multirow{3}{*}{ EDM 04} & EDM 04. 01 & Evaluate resource management \\
\hline & EDM 04. 02 & Direct resource management \\
\hline & EDM 04.03 & Monitor resource management \\
\hline \multirow{3}{*}{ APO 01} & APO 01.01 & Define the organizational structure \\
\hline & APO 01.02 & Establish roles and responsibilities \\
\hline & APO 01.03 & Maintain the enablers of the management system \\
\hline \multirow{3}{*}{ APO 02} & APO 02. 01 & Understand enterprise direction \\
\hline & APO 02.02 & $\begin{array}{l}\text { Assess the current environment, capabilities and } \\
\text { performance }\end{array}$ \\
\hline & APO 02.03 & Define the target IT capabilities \\
\hline \multirow{3}{*}{ APO 06} & APO 06. 01 & Manage finance and accounting \\
\hline & APO 06. 02 & Prioritise resource allocation \\
\hline & APO 06. 03 & Create and maintain budgets \\
\hline \multirow{3}{*}{ APO 07} & APO 07. 01 & Maintain adequate and approriate staffing \\
\hline & APO 07. 02 & Identify key IT personnel \\
\hline & APO 07.03 & Maintain the skill and competencies of personnel \\
\hline \multirow{3}{*}{ DSS 01} & DSS 01.01 & Perform operational procedures \\
\hline & DSS 01.02 & Manage outsourced IT service \\
\hline & DSS 01.03 & Monitor IT infrastructure \\
\hline \multirow{3}{*}{ DSS 03} & DSS 03. 01 & Identify and clasify problem \\
\hline & DSS 03. 02 & Investigate and diagnose problem \\
\hline & DSS 03.03 & Raise known error \\
\hline
\end{tabular}




\begin{tabular}{lll}
\hline \multirow{2}{*}{ MEA 01 } & MEA 01.01 & Establish a monitoring approach \\
\cline { 2 - 3 } & MEA 01.02 & Set performance and conformance target \\
\hline MEA 01.03 & $\begin{array}{l}\text { Collect and process performance and conformance } \\
\text { data }\end{array}$ \\
\hline MEA 03 & MEA 03.01 & Identify external compliance requirement \\
\cline { 2 - 3 } & MEA 03.02 & Optimise response to external requirement \\
\cline { 2 - 3 } & MEA 03.03 & Confirm external compliance \\
\hline
\end{tabular}

\subsection{Menetukan Tingkat Kematangan Saat Ini}

Berdasarkan rekapitulasi jawaban dari para responden (terlampir), maka didapatkan nilai tingkat kematangan saat ini pada rentang $0-5$. Selanjutnya data-data yang diperoleh tersebut dimasukkan ke dalam tabel rekapitulasi model maturity seperti pada tabel 3.3 dibawah ini :

Tabel 3.3 Rekapitulasi Tingkat Kematangan Saat Ini

\begin{tabular}{|c|c|c|c|c|}
\hline \multirow[t]{2}{*}{ Domain } & \multirow[t]{2}{*}{ Proses } & Rata-rata & \multirow{2}{*}{$\begin{array}{c}\text { Jumlah } \\
\text { Sub proses }\end{array}$} & \multirow{2}{*}{$\begin{array}{c}\text { Rata-rata } \\
\text { Proses }\end{array}$} \\
\hline & & Responden & & \\
\hline \multirow[t]{3}{*}{ EDM 03} & EDM 03. 01 & 3 & \multirow{3}{*}{9,11} & \multirow{3}{*}{3,04} \\
\hline & EDM 03. 02 & 3 & & \\
\hline & EDM 03. 03 & 3,11 & & \\
\hline \multirow{3}{*}{ EMD 04} & EDM 04. 01 & 3,11 & \multirow{3}{*}{9,44} & \multirow{3}{*}{3,15} \\
\hline & EDM 04. 02 & 3,22 & & \\
\hline & EDM 04. 03 & 3,11 & & \\
\hline \multirow[t]{3}{*}{ APO 01} & APO 01. 01 & 3,22 & \multirow{3}{*}{9,33} & \multirow{3}{*}{3,11} \\
\hline & APO 01. 02 & 3 & & \\
\hline & APO 01.03 & 3,11 & & \\
\hline \multirow[t]{3}{*}{ APO 02} & APO 02. 01 & 2,89 & \multirow{3}{*}{8,22} & \multirow{3}{*}{2,74} \\
\hline & APO 02.02 & 2,67 & & \\
\hline & APO 02.03 & 2,67 & & \\
\hline \multirow[t]{3}{*}{ APO 06} & APO 06. 01 & 3,11 & \multirow{3}{*}{9,00} & \multirow{3}{*}{3,00} \\
\hline & APO 06. 02 & 3 & & \\
\hline & APO 06. 03 & 2,89 & & \\
\hline \multirow[t]{3}{*}{ APO 07} & APO 07. 01 & 2,44 & \multirow{3}{*}{7,78} & \multirow{3}{*}{2,59} \\
\hline & APO 07. 02 & 2,44 & & \\
\hline & APO 07. 03 & 2,89 & & \\
\hline \multirow[t]{3}{*}{ DSS 01} & DSS 01.01 & 3 & \multirow{3}{*}{9,00} & \multirow{3}{*}{3,00} \\
\hline & DSS 01.02 & 2,89 & & \\
\hline & DSS 01.03 & 3,11 & & \\
\hline \multirow[t]{3}{*}{ DSS 03} & DSS 03.01 & 3 & \multirow{3}{*}{9,11} & \multirow{3}{*}{3,04} \\
\hline & DSS 03. 02 & 2,89 & & \\
\hline & DSS 03.03 & 3,22 & & \\
\hline \multirow{3}{*}{ MEA 01} & MEA 01.01 & 3,11 & \multirow{3}{*}{8,67} & \multirow{3}{*}{2,89} \\
\hline & MEA 01.02 & 2,67 & & \\
\hline & MEA 01.03 & 2,89 & & \\
\hline & MEA 03. 01 & 3 & & \\
\hline MEA 03 & MEA 03. 02 & 3,11 & 9,11 & 3,04 \\
\hline
\end{tabular}


Fajrin Rizaldi ${ }^{1}$, Aggy Pramana Gusman², Ulya Mega Wahyuni ${ }^{3}$

\begin{tabular}{ccc}
\cline { 2 - 3 } MEA 03. 03 & & \\
\hline Jumlah & 88,78 & 29,59 \\
\hline Nilai Rata-Rata Sub Proses & 8,88 & 2,96 \\
\hline Nilai Tingkat Kematangan saat ini & \\
\hline
\end{tabular}

Dengan menggunakan model maturity yang digambarkan ke dalam bentuk angka dan grafik, sehingga hal ini dapat memudahkan dalam perolehan hasil penelitian di bawah ini :

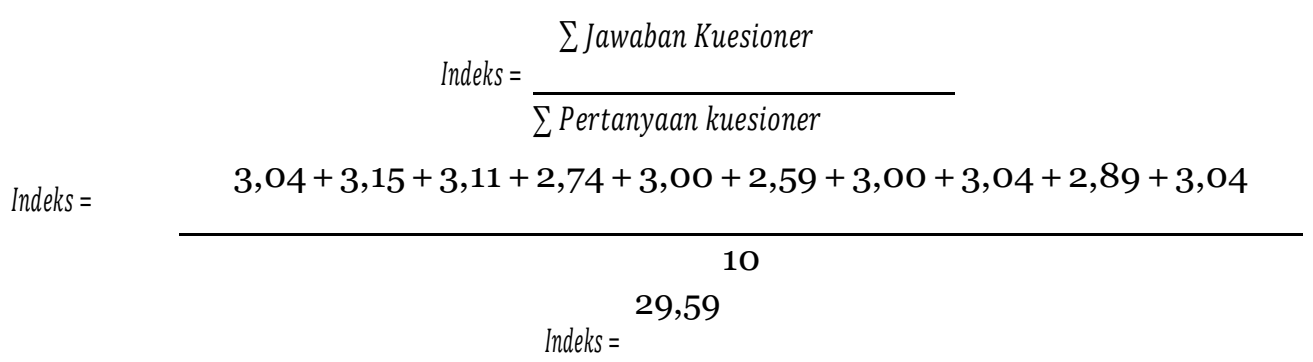

\subsection{Hasil Pengukuran Tingkat Kematangan}

Berdasarkan data yang diperoleh maka data-data yang ada akan dikelompokkan dan di sesuaikan dengan tingkat yang ada pada metode Cobit. Data tingkat kematangan tersebut di masukan kedalam dan dapat dilihat pada tabel 3.4 dibawah ini :

Tabel 3.4 Hasil Pengukuran Tingkat Kematangan Proses TI Saat Ini

\begin{tabular}{|c|c|c|}
\hline Control Proses TI & $\begin{array}{l}\text { Tingkat Kematangan } \\
\text { Saat Ini }\end{array}$ & $\begin{array}{l}\text { Skala Tingkat } \\
\text { Kematangan }\end{array}$ \\
\hline \multicolumn{3}{|l|}{ Ensure risk optimisation (EDM 03) } \\
\hline & 3,04 & Defined Process \\
\hline \multicolumn{3}{|l|}{ Ensure resource optimisation (EDM 04) } \\
\hline & 3,15 & Defined Process \\
\hline $\begin{array}{l}\text { Manage the IT management framework } \\
\text { (APO 01) }\end{array}$ & 3,11 & Defined Process \\
\hline \multicolumn{3}{|l|}{ Manage strategy } \\
\hline (APO 02) & 2,74 & Defined Process \\
\hline \multicolumn{3}{|l|}{ Manage budget and costs (APO 06) } \\
\hline & 3,00 & Defined Process \\
\hline \multicolumn{3}{|l|}{ Manage human resource (APO 07) } \\
\hline & 2,59 & Defined Process \\
\hline \multicolumn{3}{|l|}{ Manage operations } \\
\hline (DSS 01) & 3,00 & Defined Process \\
\hline \multicolumn{3}{|l|}{ Manage problems } \\
\hline (DSS 03) & 3,04 & Defined Process \\
\hline $\begin{array}{l}\text { Monitor, evaluate, and assess the system } \\
\text { of internal control (MEA 01) }\end{array}$ & 2,89 & Defined Process \\
\hline $\begin{array}{l}\text { Monitor, evaluate, and assess compliance } \\
\text { with external requirement (MEA 03) }\end{array}$ & 3,04 & Defined Process \\
\hline Total Nilai Tingkat Kematangan & 2,96 & Defined Process \\
\hline
\end{tabular}


Setelah menilai dan mengetahui tingkat kematangan tata kelola teknologi informasi pada Stasiun Meteorologi Maritim Teluk Bayur saat ini sebesar 2,96 dengan tingkat defined process. Untuk tingkat kematangan teknologi informasi yang diharapkan sebesar 4 dengan tingkat kematangan Manage And Measurable.

Berdasarkan data yang diperoleh maka data-data yang ada akan dikelompokkan dan di sesuaikan dengan tingkat yang ada pada metode Cobit. Data tingkat kematangan tersebut di masukan kedalam dan dapat dilihat pada tabel 3.4 dibawah ini :

Tabel 3.4 Hasil Pengukuran Tingkat Kematangan Proses TI Saat Ini

\begin{tabular}{lcc}
\hline \multicolumn{1}{c}{ Control Proses TI } & $\begin{array}{c}\text { Tingkat Kematangan } \\
\text { Saat Ini }\end{array}$ & $\begin{array}{c}\text { Skala Tingkat } \\
\text { Kematangan }\end{array}$ \\
\hline $\begin{array}{l}\text { Ensure risk optimisation (EDM 03) } \\
\text { Ensure resource optimisation (EDM 04) }\end{array}$ & 3,04 & Defined Process \\
\hline $\begin{array}{l}\text { Manage the IT management framework } \\
\text { (APO 01) }\end{array}$ & 3,15 & Defined Process \\
\hline $\begin{array}{l}\text { Manage strategy } \\
\text { (APO 02) }\end{array}$ & 3,11 & Defined Process \\
\hline $\begin{array}{l}\text { Manage budget and costs (APO 06) } \\
\text { Manage human resource (APO 07) }\end{array}$ & 2,74 & Defined Process \\
\hline $\begin{array}{l}\text { Manage operations } \\
\text { (DSS 01) }\end{array}$ & 3,00 & Defined Process \\
\hline $\begin{array}{l}\text { Manage problems } \\
\text { (DSS 03) }\end{array}$ & 2,59 & Defined Process \\
\hline $\begin{array}{l}\text { Monitor, evaluate, and assess the system } \\
\text { of internal control (MEA 01) }\end{array}$ & 3,00 & Defined Process \\
\hline $\begin{array}{l}\text { Monitor, evaluate, and assess compliance } \\
\text { with external requirement (MEA 03) }\end{array}$ & 3,04 & Defined Process \\
\hline
\end{tabular}

Setelah menilai dan mengetahui tingkat kematangan tata kelola teknologi informasi pada Stasiun Meteorologi Maritim Teluk Bayur saat ini sebesar 2,96 dengan tingkat defined process. Untuk tingkat kematangan teknologi informasi yang diharapkan sebesar 4 dengan tingkat kematangan Manage And Measurable.

\subsection{Menentukan Nilai GAP Atau Kesenjangan}

Dari hasil di atas, maka dilakukan analisis untuk menunjukkan kesenjangan/gap antara tingkat kematangan saat ini dengan tingkat kematangan yang diharapkan, tertera pada tabel 3.5 dibawah ini : 
Tabel 3.5 Perbandingan Tingkat Kematangan

\begin{tabular}{|c|c|c|c|}
\hline \multirow[b]{2}{*}{ Control Proses TI } & \multicolumn{3}{|c|}{ Tingkat Kematangan } \\
\hline & Saat Ini & Diharapkan & $\begin{array}{c}\text { GAP }=(\text { Diharapkan- } \\
\text { Saat Ini })\end{array}$ \\
\hline $\begin{array}{l}\text { Ensure risk optimisation } \\
\text { (EDM 03) }\end{array}$ & 3,04 & 4 & 0,96 \\
\hline $\begin{array}{l}\text { Ensure resource optimisation (EDM } \\
04)\end{array}$ & 3,15 & 4 & 0,85 \\
\hline $\begin{array}{l}\text { Manage the IT management } \\
\text { framework (APO 01) }\end{array}$ & 3,11 & 4 & 0,89 \\
\hline $\begin{array}{l}\text { Manage strategy } \\
\text { (APO 02) }\end{array}$ & 2,74 & 4 & 1,26 \\
\hline Manage budget and costs (APO 06) & 3,00 & 4 & 1 \\
\hline Manage human resource (APO 07) & 2,59 & 4 & 1,41 \\
\hline $\begin{array}{l}\text { Manage operations } \\
\text { (DSS 01) }\end{array}$ & 3,00 & 4 & 1 \\
\hline $\begin{array}{l}\text { Manage problems } \\
\text { (DSS 03) }\end{array}$ & 3,04 & 4 & 0,96 \\
\hline $\begin{array}{l}\text { Monitor, evaluate, and assess the } \\
\text { system of internal control (MEA 01) }\end{array}$ & 2,89 & 4 & 1,11 \\
\hline $\begin{array}{l}\text { Monitor, evaluate, and assess } \\
\text { compliance with } \\
\text { requirement (MEA 03) }\end{array}$ & 3,04 & 4 & 0,96 \\
\hline Rata-Rata & & & 1,04 \\
\hline
\end{tabular}

Rata-rata gap atau kesenjangan pada seluruh domain proses yang diteliti sebesar 1,04. Nilai 1,04 adalah perbedaaan antara nilai kematangan saat ini dengan tingkat kematangan yang diharapkan. Perbedaan kondisi kesenjangan tata kelola seluruh domain proses saat ini dengan nilai yang diharapkan, dapat digambarkan dalam Grafik 4.1 sebagai berikut :

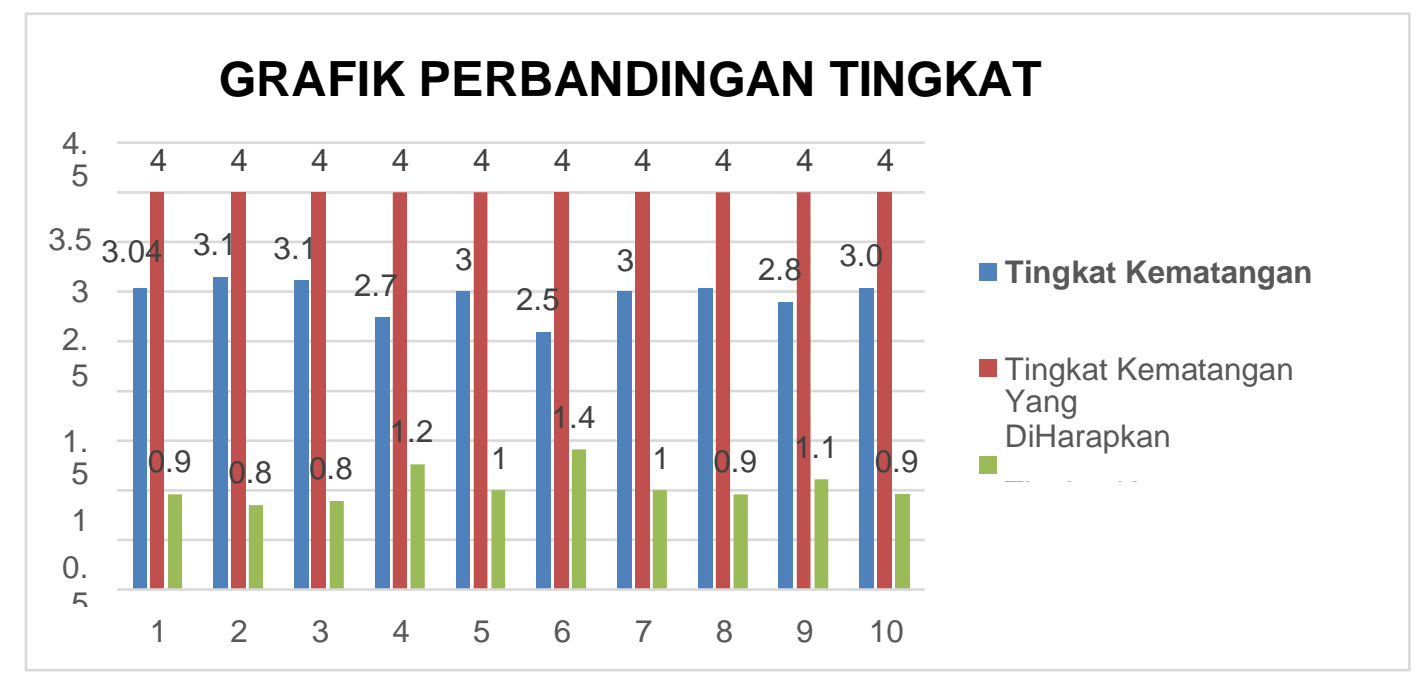

Grafik 3.1 Grafik Perbandingan Tingkat Kematangan 


\section{Penutup}

\subsection{Kesimpulan}

Hasil pengolahan data dari tabulasi data, rata-rata nilai kematangan untuk Stasiun Meteorologi Maritim Teluk Bayur adalah 2,96. Ini menunjukkan bahwa dalam melaksanakan tata kelola teknologi informasi telah melakukan prosedur yang terstandarisasi, terdokumentasi, dan telah dikomunikasikan melalui pelatihan dan media. Tetapi masih ditemukan permasalahan ditingkat pelaksana dan staff sehingga perlu dilakukan perbaikan-perbaikan yang lebih baik kedepannya. Berdasarkan hasil penelitian dan pembahasan, maka dapat disimpulkan sebagai berikut:

1. Bahwa Stasiun Meteorologi Maritim Teluk Bayur berada pada maturity level skala 3 yaitu seluruh proses didokumentasikan dan dikomunikasikan, serta dilaksanakan berdasarkan metode pengembangan system komputerisasi yang baik, namun belum ada proses evaluasi terhadap system tersebut yang telah diimplementasikan.

2. Dalam penelitian didapatkan nilai tertinggi dan nilai terendah yang didapatkan berdasarkan perhitungan yang dilakukan dengan menggunakan data-data yang diperoleh. Masing-masing domain memiliki proses yang berbeda seperti pada APO 07 merujuk pada pengelolaan sumber daya manusia. Oleh sebab itu, nilai-nilai yang diperoleh dari perhitungan bisa menjadi patokan seberapa jauh tata kelola TI diterapkan di perusahaan. Pada kesimpulan penulis mengambil nilai tertinggi dan nilai terendah dari proses perhitungan yang dilakukan sebelumnya.

\section{A. Nilai Kematangan Tertinggi}

Nilai kematangan tertinggi berada pada domain EDM 04 yaitu memastikan optimalisasi sumber daya dengan nilai kematangan 3.15. Dalam hal ini pada EDM 04 bertujuan bahwa kebutuhan sumber daya perusahaan terpenuhi dengan cara yang optimal, biaya TI dioptimalkan, memungkinkan peningkatan realisasi keuntungan, serta kesiapan untuk perubahan di masa depan. Berdasarkan penelitian yang dilakukan, perusahaan mampu mengoptimalkan sumber daya yang ada dan pemanfaatan biaya telah dilakukan dengan baik. Diharapkan perushaan mampu untuk terus meningkatkan dan terus melanjutkan kinerja yang telah cukup baik ini.

\section{B. Nilai Kematangan Terendah}

Nilai kematangan terendah berada pada proses APO 07 yaitu pengelolaan sumber daya manusia dengan nilai kematangan 2,59.. Dalam hal ini perusahaan belum secara optimal dan terkonsistensi dalam melakukan hal tersebut secara berkesinambungan. Hal ini disebabkan beberapa faktor antara lain belum optimalnya menverifikasi personal yang memiliki kompetensi dalam memenuhi peran berdasarkan pelatihan atau pengalaman staff IT. Dan evaluasi yang dilakukan belum sesuai dengan tujuan individu itu sendiri atau petepatan waktu dalam melakukan evaluasi perlu ditingkatkan. Diharapkan perusahaan mampu untuk meningkatkan kinerja diperushaaan agar tujuan perusahaan dapat tercapai.

3. Penelitian dilakukan dengan tujuan membantu perusahaan dalam mengamati setiap kinerja TI dan tata kelola TI yang memungkinkan untuk ditingkatkan, sehingga tujuan dari perusahaan itu sendiri dapat tercapai. Teknologi informasi yang mencakup penentuan perencanaan strategis, resiko, sumber daya teknologi informasi, kinerja berdasarkan kebijakan dan peraturan yang ada, untuk mencapai pengelolaan teknologi informasi yang baik. Oleh sebab itu penelitian dilakukan untuk menunjang kinerja organisais atau perusahaan itu sendiri.

\section{DAFTAR RUJUKAN}

[1] Sutomo, B dan M. Adie Saputra., 2017. Perancangan Tata Kelola Teknologi Informasi Pada Perguruan Tinggi Dengan Menggunakan Framework Cobit 5 Studi Kasus : Stmik Dharma Wacana Metro. Jurnal Sistem Informasi dan Teknik Informatika, 1 (1), pp.28-43.

[2] Oktarina, Tri., 2017. Tata Kelola Teknologi Informasi Dengan Cobit 5. Jurnal Informatika, 3 (2), pp. 30-38.

[3] Hadi, A. F., Permana, R., \& Syafwan, H. (2019, December). Decision Support System in Determining Structural Position Mutations Using Simple Additive Weighting (SAW) Method. In Journal of Physics: Conference Series (Vol. 1339, No. 1, p. 012015). IOP Publishing 